\title{
A primeira modernidade e seu contexto intelectual: subordinação política e mundialização ${ }^{1}$
}

Rubens Leonardo Panegassi*

Resumo: O objetivo deste artigo é circunscrever o contexto intelectual característico da formação do mundo moderno enquanto espaço de circulação de ideias e juízos diversos. Para isso, recuperamos o senso de ordem social próprio do imaginário europeu da primeira modernidade a partir de diferentes registros literários produzidos no contexto do Renascimento ibérico. Esta literatura nos remete ao ideário do cristianismo primitivo, referência intelectual coerente aos propósitos espirituais da mundialização levada a cabo por espanhóis e portugueses. Verificamos que embora as concepções etnológicas da primeira modernidade sejam tributárias do pensamento patrístico, encontram-se atreladas à experiência estatal moderna. Diante disso, concluímos que a sujeição política foi a tônica dominante do fenômeno da mundialização.

Palavras-chave: Mundialização ibérica. Cristianismo primitivo. Subordinação política.

\section{Tessituras do mundo moderno}

A mundialização levada a cabo pelos reinos ibéricos no contexto da primeira modernidade estabeleceu um campo de circulação de ideias a partir de uma grade de leitura hierarquizadora. Calcada no pressuposto de que tudo possuía uma ordenação definida desde a origem do mundo e da criação da humanidade, esta perspectiva

\footnotetext{
* Doutor em História pela Universidade de São Paulo - USP. Professor de História Moderna e Contemporânea da Universidade Federal de Viçosa - UFV. E-mail: rubenspanegassi@gmail.com.br
}

Anos 90, Porto Alegre, v. 24, n. 45, p. 45-72, jul. 2017 
estruturou-se a partir de uma classificação dual da espécie humana, orientada tanto por sua filiação religiosa, quanto pelo nível e complexidade de sua civilização.

Esta divisão nos remete ao debate sobre a ideia de humanidade que acompanhou a formação do mundo moderno, e orientou a composição de pontes cognitivas entre a Europa e os mais diversos povos e culturas. Por sua vez, as crônicas produzidas neste momento fornecem elementos substantivos a respeito das referências que instrumentalizaram a composição de um imaginário que teceu, paulatinamente, uma relação de continuidade entre as mais distantes partes do mundo.

\section{Referências normativas compartilhadas: o Atlântico e o mundo}

O ponto de partida deste artigo define com precisão um campo de problemas inerente à dimensão planetária característica da formação do mundo moderno enquanto espaço de circulação de ideias e juízos diversos. Partindo da noção de mobilização sugerida por Serge Gruzinski para a recuperação da densidade dos feitos ibéricos sobre o globo (GRUZINSKI, 2014), nosso interesse é sublinhar a eficácia dos artifícios de codificação que acompanharam este fenômeno, uma vez que são responsáveis pela estruturação de inúmeros estereótipos, bem como pelas diferentes modalidades de segregação que historicamente regeram a interação entre as mais distantes partes do mundo.

Um primeiro movimento para a percepção da dinâmica inerente à conexão entre as diversas populações do orbe e a peculiaridade deste processo em termos de delimitação de um imaginário marcado por um profundo sentido de ordenação é visível, por exemplo, na Historia naturaly moral de las Indias, crônica escrita pelo jesuíta José de Acosta e publicada no ano de 1590, em Sevilha. Documento de primeira ordem para a História das sociedades americanas, a obra de Acosta oferece um excelente reservatório de conhecimentos que rapidamente se difundiu pelo mundo a partir do Atlântico e suas conexões. Efetivamente, os portugueses na Ásia liam "os espanhóis que frequantaram a América, 
e vice-versa" (GRUZINSKI, 2014,p. 240). Dentre os inúmeros assuntos abordados na obra, gostaríamos de atentar para a descrição que Acosta fez dos gêneros alimentares utilizados pelos povos americanos: para além de uma formidável descrição dos usos, costumes e vida material local, nota-se um olhar direcionado por um quadro de referências normativo, que assinala um sutil procedimento de hierarquização.

Em síntese, o jesuíta parte da premissa de que o principal mantimento do homem é o pão, e de que existe um termo correspondente a este alimento no vocabulário das populações autóctones da América. Com isso, reconhece que o pão indígena possui outra qualidade por não ser feito de trigo, e sim de outros tipos de grãos, como o milho. O trigo, relata o cronista, "que é o principal sustento dos homens", é precedido pelo milho "para sustento de homens e animais"2 (ACOSTA, 1962, p. 267). A assertiva do religioso sobre os hábitos alimentares indígenas ganha relevância à medida que, tanto quanto a linguagem ou a religião, a alimentação pode ser compreendida como matriz identitária ou, em termos mais específicos, como fundamento etnocêntrico (VALERI, 1989).

Se, por um lado, a sumária recuperação do cronista espanhol denota nosso esforço em sublinhar a dimensão atlântica de um horizonte intelectual que pretendemos explorar em âmbito mundial, por outro lado atenta para a peculiaridade de seu escrito, uma vez que antes de hierarquizar, Acosta define um intrumento de comparação ao reconhecer a existência do termo pão no léxico indígena. Termo cuja conotação simbólica é da mais alta relevância no âmbito do cristanismo (CHÂTELET, 1985; MONTANARI, 2003). Sem dúvida, ao passo que a formação do mundo moderno assinala o primeiro momento de um irreversível processo de conexão entre povos e culturas em escala global, também define padrões de comparação que a longo prazo darão suporte às divisões políticas, culturais e ideológicas que orientarão a composição da ordem mundial.

Por sua vez, o lugar epistemológico de onde José de Acosta faz seu enunciado é compartilhado por outros cronistas, tal como o português João de Barros, autor das Décadas da Ásia. Publicada entre 1552 e 1563, as Décadas nos apresentam "o mundo de um ponto de vista múltiplo e segundo uma escala planetária” (SARAIVA, 1972, p. 355). Ponto de vista 
evidente em sua irônica apreciação das críticas veiculadas pelos opositores do Infante Dom Henrique e seus empreendimentos marítimos, onde Barros nos relata que o foco dos críticos incidia sobre a incerteza a respeito dos objetivos das conquistas, e na sugestão de que o infante se contentasse "com a terra que ora temos, a qual Deus deu por termo e habitação dos homens; e se alguma houver onde o Infante diz, devemos crer que Ele a deixou para pasto dos brutos"' (BARROS, 1778, p. 38). É notório que o cronista português reitera a hierarquização subjacente à própria codificação das diferenças que as narrativas produzidas em decorrencia da mobilização ibérica criaram. Mais que isso, o excerto de João de Barros esclarece que a ordenação do mundo tem um pressuposto divino que reserva parte dele à "habitação dos homens", ao passo que a outra parte era destinada a ser "pasto dos brutos".

A oposição sugerida pelo historiador quinhentista ganha contornos mais bem definidos em sua descrição do diálogo travado no contexto do governo de D. João II, entre o fidalgo Diogo de Azambuja e Caramansa, régulo da Guiné. Segundo Barros, o português oferecia ao rei africano nada menos que a salvação de sua alma em troca de uma aliança política, visto que "era amor da salvação de sua alma, coisa mais preciosa que os homens tinham, por ela ser a que lhe dava vida, entendimento para conhecer e entender todas as coisas, e pela qual o homem era diferente dos brutos"5 (BARROS, 1778, p. 159).

Oportunamente, John H. Elliott sugeriu que os interesses em explorar recursos naturais, somados à conversão religiosa e ao governo das populações locais foram as principais motivações que os europeus tiveram para ampliar sua visão de mundo, organizando e classificando sua experiência na América a partir de um enquadramento coerente de pensamento. Este enquadramento alinhava-se à herança clássica e judaico-cristã, que suscitou uma classificação dual da humanidade, ordenada quer por sua filiação religiosa, quer por seu grau de civilização. Em suma, paralelamente ao interesse epistemológico, havia o imperativo de incorporar a diversidade tão rápido quanto fosse possível à "república cristã" (ELLIOTT, 1984).

Tanto José de Acosta quanto João de Barros fazem uso de um critério de classificação que pressupõe uma diferenciação fundamental entre os homens. No caso do cronista português, cujo objeto 
da obra é a própria mobilização lusa e os vínculos que se estabeleciam entre as quatro partes do mundo, fica mais notório seu esforço em estabelecer uma relação de continuidade entre regiões, povos e imaginários em escala mundial. Com efeito, a intríseca relação estabelecida pelo cronista entre alma e entendimento denota, sem dúvida, a mediação de ambas heranças referidas por Elliott neste processo: enquanto a tradição cristã definia o homem em termos da sua receptividade da graça divina - alma -, a tradição clássica definia-o nos termos de sua racionalidade - entendimento. Em suma, as conexões entre Europa, América, África e Ásia foram orientadas por um pressuposto em que se articulavam uma dimensão religiosa - que dividia a humanidade entre cristãos e não cristãos (pagãos, infiéis e gentios) - e uma dimensão política proveniente da literatura clássica - que separava o grego do bárbaro (ELLIOTT, 1984).

Esta divisão nos remete a um debate sobre a noção de humanidade que atravessa a história das ideias etnológicas. Em síntese, a abrangência que esta noção alcançou soaria estranha à maioria das sociedades durante a maior parte da história (FERNÁNDEZ-ARMESTO, 2007). Autores como Margaret T. Hodgen (1964) e, mais recentemente Matthew R. Goodrum (2002), Joan-Pau Rubiés (2002), Felipe Fernandez-Armesto (2007) e David Abulafia (2008) ${ }^{6}$ se debruçaram sobre este assunto a partir de diferentes aspectos e atentaram ao fato de que o pensamento do cristianismo primitivo e as ideias do alto medievo - marcadas simultaneamente pelas sagradas escrituras e por ingredientes pagãos, fantásticos, monstruosos e fabulosos - tiveram impacto significativo sobre o ideário etnológico da primeira modernidade. De todo modo, o pressuposto bíblico da descendência do gênero humano a partir de um único par de genitores levou o pensamento etnológico a incorporar o pressuposto universalista do cristianismo como o elemento mediador das relações com os mais diversos povos e culturas ao longo do processo de mundialização que os reinos ibéricos estimularam.

Por sua vez, a definição de um horizonte intelectual planetário damandou a confecção de uma relação de continuidade entre as sociedades, o que abriu espaço para a discussão sobre a humanidade e seus limites, cujo ápice foi o debate entre Bartolomeu de Las Casas e Juan Ginez de Sepúlveda em Valladolid, entre 1550 e 1551 
(PAGDEN, 1988). Este embate, que por um lado denota o eco das proposições aristotélicas a respeito da escravidão natural, por outro nos remete às reações da filosofia patrística ao naturalismo característico do pensamento pagão a respeito da ideia de humanidade.

\section{Artifícios de codificação e pressupostos intelectuais}

As reações da filosofia patrística ao naturalismo pagão foi objeto de estudo do historiador Matthew Goodrum, que circunscreveu este embate a partir das respostas dos apologetas cristãos ao paganismo, notavelmente a Demócrito de Abdera. Com efeito, as ideias de Demócrito são conhecidas essencialmente a partir de seus comentaristas. E foi mediado pela pena de um dos mais importantes apologetas do cristianismo que as ideias do filósofo grego ganharam seus contornos mais naturalistas: em sua obra Instituições Divinas (302-311 d.C.), Lucio Célio Firmiano Lactâncio, no intuito de refutar a cosmogonia pagã, escreve que Demócrito sugere terem os homens saído "da terra, à maneira dos vermes, sem terem sido criados por alguma razão especial” (DÉMOCRITE, 1993, p. 92).7

Com efeito, no que tange à concepção da origem da espécie humana, a perspectiva atribuída a Demócrito de Abdera se desenha por meio da ação de agentes naturais, invocados para explicar o fenômeno. Entretanto, esta concepção foi combatida pela filosofia do cristianismo primitivo: ao passo que Demócrito entendia a criação do homem a partir de processos caóticos orientados pela lei da natureza, o cristianismo entendia a criação do homem a partir do preussuposto bíblico da descendência do gênero humano de um único par de genitores: a criação do homem era compreendida como um ato singular, divino e orientado pelo plano de criação de Deus, onde o homem ocuparia o topo da hierarquia da criação (GOODRUM, 2002). Em linhas gerais, esta ordenação ocupou um lugar central no imaginário social, político e jurídico da Época Moderna (HESPANHA, 2010). Definitivamente, a produção intelectual patrística não pode ser esquecida como elemento de peso nas concepções etnológicas do século XVI. Vale lembrar que foi

Anos 90, Porto Alegre, v. 24, n. 45, p. 45-72, jul. 2017 
com o Concílio de Nicéia que a heresia adquiriu o significado que se perpetuou ao longo de toda a Época Moderna (AGNOLIN, 2007).

Efetivamente, este debate sobre o problema da origem e da natureza do homem orientou parte dos escritos dos filósofos cristãos. No Estrômatos (198-203 d.C.), miscelânea composta por Clemente de Alexandria, ele foi posto em evidência pelo teólogo, que nos assugura ser por meio da "investigação sobre a origem do mundo que se poderá penetrar a natureza humana" (CLÉMENT D'ALEXANDRIE, 2001, p. 95). Em suma, a questão se articula, em última instância, ao aforismo grego inscrito nos pórticos do oráculo de Delfos: “conhece-te a ti mesmo" (FOUCAULT, 2004). É esta a problemática que orientou a filosofia patrística e seu debate a respeito da natureza da espécie humana. É neste sentido, por exemplo, que no diálogo Octavio (II-III d.C.), Marco Minúcio Félix assinalou que a importância de se conhecer a natureza humana é sustentada sob a perspectiva de que a ordem e a variedade do universo manifesta a existência de Deus. Com efeito, o apologeta aponta para o mesmo caminho dos termos do debate já apresentado:

Não nego que Cecilo tenha se esforçado em sublinhar a importância de que o homem deve conhecer-se a si mesmo e examinar quem é, de onde vem, por que existe, se é um agregado de elementos, um composto de átomos ou [...] animado por Deus. Isto não podemos, contudo, explorá-lo e descobrí-lo sem investigar todo o universo, pois todas as coisas se acham tão vinculadas, conectadas e concatenadas, que se não se tiver examinado com atenção a natureza da divinidade, não se pode conhecer a da humanidade, nem se pode tão pouco dirigir bem os assuntos civis se não se conhece antes essa cidade comum a todos que é o mundo; sobretudo, se tivermos em conta que nos diferenciamos das bestas pelo fato de que estas, inclinadas e voltadas em direção à terra, não nasceram senão para enchergar o pasto, enquanto nós, providos de um rosto erguido e de um olhar dirigido ao céu, a quem nos foi dada a palavra e a razão mediante as quais podemos conhecer, compreender e imitar a Deus, não nos está permitido nem nos é lícito ignorar a claridade celeste que se impõe a nossos olhos e a nossos sentidos; 
A primeira modernidade e seu contexto intelectual...

é um grande sacrilégio buscar na terra o que se deve encontrar nas alturas (FÉLIX, 2000, p. 83-84).

Minúcio Félix reveste o ideário pagão de uma perspectiva cristã: é possível encontrarmos opiniões semelhantes em obras como o tratado sobre $A$ natureza dos deuses (45 a.C.), de autoria de Marco Túlio Cícero ou no poema Metamorfoses (8 d.C.) de Públio Ovídio Nasão. Para Cícero, por exemplo, a natureza teria feito do homem um ser que, "ao invés de ser curvado para o chão, possui tronco alto e ereto, para que possa contemplar o céu e tomar consciência dos deuses" (CICÉRON, 1935. p. 229). Em suma, na pena do escritor romano, enquanto habitantes da terra, os homens teriam o privilégio de apreciar o "mundo supraterrestre e divino, espetáculo que não é oferecido a qualquer outra espécie animal" (CICÉRON, 1935. p. 229). ${ }^{8}$ Por sua vez, ao tratar da criação do homem, Ovídio registra ser ele o detentor da mais alta inteligência:

Ente, que a todos legislar pudesse:

Eis o homem nasce, e - ou tu, suprema Origem

De melhor Natureza, e quanto há nela,

Ou tu, pasmoso Artífice, o formaste

Pura extração de divinal semente,

Ou a Terra ainda nova, inda de fresco

Separada dos céus, lhe tinha o germe.

Com águas fluviais embrandecida,

Dela o filho de Jápeto afeiçoa,

Organiza porções, e as assemelha

Aos entes imortais, que regem tudo.

As outras criaturas debruçadas

Olhando a Terra estão; porém ao homem

O Factor conferiu sublime rosto,

Erguido para o céu lhe deu que olhasse

(OVÍDIO, 2007. p. 43-45). 
Ainda que a interação das perspectivas sobre a espécie humana oferecidas tanto por Cícero, quanto por Ovídio, tenham sido passíveis de uma apropriação intelectual, tal como a de Minúcio Félix, visto que sustentam a ideia da superioridade do homem em relação aos outros seres, importa notar a existência de um pressuposto naturalista, orientado pelo caos, que marca a obra do poeta latino:

Não tinha mais que um rosto a Natureza:

Este era o Caos, massa indigesta, rude,

E consistente só num peso inerte

(OVÍDIO, 2007. p. 39).

Com efeito, ao passo que a Patrística podia apropriar-se de parte do pensamento pagão a respeito da definição do homem, como já mencionamos anteriormente, a tese de que o homem surgiu ao acaso do caos não podia ser aceita. No segundo livro das Instituições divinas, em suas refutações à cosmogonia pagã, Lactâncio rebate a concepção do poeta latino segundo a qual o caos e a confusão teriam caracterizado o momento da criação do homem (LACTANCE, 1987, p. 115). ${ }^{9}$ Embora a tese da geração espontânea fosse inconcebível para o caso do homem, visto que ele teria sido criado diretamente por Deus e à sua imagem e semelhança, ela não era totalmente absurda para a filosofia Patrística, uma vez que, segundo o próprio livro de Gênesis, o Criador teria dito: "Que a terra produza seres vivos segundo sua espécie" (Gn 1, 24). Em face disso, em suas homilias sobre os seis dias da criação do mundo - o Hexamerão (IV d.C.) -, Basílio de Cesareia anuncia ver "a lama sozinha produzir enguias, que não procedem de nenhum ovo, nem de qualquer outra forma, é a terra sozinha que lhes dá nascimento" (BASIL, 2004, p. 102). No que tange ao homem, São Basílio anota ter a "cabeça voltada para o céu e os olhos para cima", o que denota seu "crescimento celestial" (BASIL, 2004, p. 102), acima de todos os outros seres, "tanto pela dignidade de sua conformação corporal como pela dignidade de sua alma" (BASIL, 2004, p. 102). ${ }^{10}$ Em síntese, a posição ereta do homem estaria associada ao próprio uso racional do corpo, notavelmente das mãos, as quais, segundo Gregório de Nissa escreveu no 
tratado Sobre a criação do homem (375-379 d.C.), pode facilmente produzir "toda arte e toda operação, tanto na guerra quanto na paz" e foram acrescentadas ao corpo humano "por uma questão racional" (GREGORY OF NYSSA, 2004, p. 394). ${ }^{11}$

A percepção de que existia uma ordem universal era comum ao imaginário europeu da primeira modernidade. Imperava a ideia de que tudo possuia uma ordenação que fora definida desde a origem do mundo e da criação da humanidade (HESPANHA, 2001). Vale ainda assinalarmos a importância de nomes como Demócrito e Lactâncio na cultura do Renascimento. Para reforçarmos nosso argumento, não seria fora de propósito atentarmos à figuração do filósofo grego no afresco que Donato Bramente fez para o cortesão e poeta Gaspare Visconti. ${ }^{12}$ Além disso, Lactâncio, que foi um dos principais difusores das concepções de Demócrito de Abdera no contexto, foi oportunamente comparado a Cícero pelo humanista Giovanni Pico della Mirandola (COLOT, 2015).

Assim, mapear o embate a respeito da criação do homem atende a nosso interesse em recuperar o efetivo pressuposto intelectual que não apenas estabeleceu pontes cognitivas, mas que também fundamentou e justificou ações no contexto da mundialização ibérica. Nosso interesse, agora, será delinear os ecos deste debate a partir da pena de João de Barros, cronista cujo horizonte estava atento à conexão de regiões e culturas em escala planetária.

\section{Religião e política: horizonte inclusivo e subordinação}

Como já assinalamos, os escritos de João de Barros nos fornecem elementos substantivos a respeito das conexões do Renascimento português com outras grandes civilizações do mundo. Efetivamente, seu inventário das diferenças orientava-se por uma perspectiva de conjunto coerente a um empreendimento espiritual, que procurava articular todas as extremidades do mundo. Das apropriações feitas por João de Barros da literatura antiga, bem como sua utilização dos textos dos primeiros filósofos cristãos, I. S. Révah nos deu notícias em artigo seminal (RÉVAH, 1967). 
No que tange ao debate sobre a origem da espécie humana, ainda que o humanista não o recupere como objeto, é possível apontarmos alguns momentos em em que o historiador quinhentista tangencia o assunto, particularmente em dois pontos onde encontramos referências às Metamorfoses de Ovídio e às Instituições divinas de Lactâncio, ambas em seu diálogo Ropicapnefma, de 1532. Da menção ao apologeta cristão foi I. S. Révah quem nos chamou a atenção onde lemos:

A alma, enquanto está retida em o cárcere do corpo, sentindo corruptas paixões, dá lugar às mortais dores. Mas tanto que o corpo é corrompido e ela acha a liberdade, é levada ao céu, onde está eternamente sem pena, porque assim o despôs a divina Providência (BARROS, 1983, p. 61).

Para Révah, o excerto nos remete ao sétimo livro das Instituições divinas: mais especificamente, é possível sugerir que a transcrição refere-se ao capítulo sobre a imortalidade da alma. Todavia, além da menção a Lactâncio em sua discussão a respeito da imortalidade da alma, Barros também faz referência literal a Ovídio ao anotar:"Deu o Fabricador de todas as coisas ao homem rosto alto e mandou-lhe contemplar o céu; não o fez, como os outros animais, com ele derrubado, curvo e posto na terra" (BARROS, 1983, p. 61). O que podemos notar, portanto, é sua necessidade em demarcar a fronteira entre homens e animais. Em suma, Barros estende à esfera planetária o artifício de uma Antiguidade religiosa de notável eficácia na demarcação das diferenças. Artifício reconhecido pela antropologia contemporânea, e que levaria Edmund Leach a admitir a inexistência de "uma linha de demarcação nítida entre a Natureza e a Cultura" (LEACH, 1985, p. 139).

O debate a respeito das diferenças entre os homens e os animais nos remete às discussões sobre a própria origem da espécie humana e colabora na construção de uma doutrina em que transparecem as exigências sociais cristãs. Segundo Adone Agnolin:

O século IV representa [...] o marco de uma cristandade que adquire uma forma histórica caracterizada pela unidade 
doutrinária e eclesiástica, fundamentada no caráter majoritário e, por consequência, necessariamente sujeita a fracionamentos minoritários que adquirem o nome de heresias ou cismas (AGNOLIN, 2007, p. 131).

Além disso, assinala a histórica relação que se estabeleceu entre a esfera religiosa e a esfera política. Ainda que seja possível especificarmos que o peso da pregação cristã como fonte de inspiração das reflexões sobre o poder tenha alcançado seu ápice entre os séculos V e XII, não podemos perder de vista que o plano político e religioso permaneceriam entrelaçados mesmo após a renovação da filosofia e do direito levada a cabo pelos humanistas (NAY, 2007).

Uma vez que nosso interesse é indagar a respeito dos pressupostos inerentes às ideias que acompanharam a formação do mundo moderno e a composição de um imaginário em escala planetária, importa observar que a histórica relação estabelecida entre religião e política foi acompanhada por uma desconfiança judaico-cristã em relação ao poder laico: enquanto gregos e romanos confiavam nas virtudes cívicas e na organização da cidade como espaço de relização do cidadão, os homens da Bíblia desprezavam os poderes temporais com a certeza de que a justiça era um assunto fundamentalmente divino. Além disso, entendiam a cidade como lugar de devassidão e corrupção (NAY, 2007). Quando nos deparamos com o ideário do cristianismo primitivo, segundo o qual a boa direção dos assuntos civis deve ser entregue ao homem por sua capacidade de fazer o uso da razão - dentro de uma significativa articulação com sua capacidade de contemplar e imitar a Deus em diferenciação das bestas -, estamos nos defrontando, em última instância, com o ideal de cidadão - bem como de seu oposto, o bárbaro - concebido por Aristóteles em sua Política (325 a.C.), todavia, já revestido pelos fundamentos doutrinais da religião cristã. Em síntese, “a ‘cidade de Deus’ é potencialmente aberta a todas as gentes e a 'doctrina christiana' compatibilizou, de fato, todas as elaborações universalistas da Antiguidade pagã, da filosofia grega ao direito romano" (GASBARRO, 2006, p. 76). Especificamente no que tange à diferenciação entre o bárbaro e o cidadão, a autoridade das sagradas escrituras e do pensamento 
patrístico se articulam a um pensamento de orientação filosófica preponderantemente aristotélica.

Como vimos, para o apologeta Minúcio Félix, a capacidade do uso racional do corpo e da palavra, credenciam o homem a dirigir os assuntos civis da "cidade comum a todos que é o mundo" (FÉLIX, 2000, p. 84). A estabilização desta concepção foi mediada pela filosofia Patrística que se desdobra da noção desenhada por Aristóteles em sua Política, segundo a qual o homem é um animal cívico. Em suma, o Estagirita argumenta que a dependência mútua inscreve a vida social nos desígnios da natureza, de modo que estando a cidade na natureza, o homem é naturalmente feito para a vida política: por ser um animal cívico o homem foi agraciado com o dom da fala, elemento articulador de toda a sociedade civil. Em linhas gerais, sua ideia é de que nenhum homem pode bastar-se por si mesmo e aquele que não depende de outros homens, ou é um deus, ou um bruto. Em síntese, a fala projeta o homem no plano da vida política (ARISTÓTELES, 2006).

Ainda segundo o filósofo grego, este pressuposto hierarquizador é uma resposta natural da sociedade, que para sua autoconservação demanda uma estrutura na qual alguém exerce a função de comando, enquanto outro submete-se. Ou seja, todos estão marcados desde seu nascimento para o comando, ou para a submissão. É desígnio da natureza que os mais inteligentes comandem aqueles que não possam contribuir com nada além do trabalho do seu corpo para a prosperidade comum: "todos os que não têm nada melhor para nos oferecer de que o uso de seus corpos e de seus membros são condenados pela natureza à escravidão" (ARISTÓTELES, 2006, p. 13), argumenta. Entretanto, ainda em sua perspectiva, o mando é tão mais nobre quanto mais elevado é o súdito: mais vale comandar homens do que animais, escreve em sua Política (ARISTÓTELES, 2006, p. 13). E sob esta perspectiva que devemos compreender a ideia de que $\mathrm{o}$ príncipe é tido como o rei dos costumes, tal como sugere mais uma vez João de Barros em sua Ropicapnefma:

Lugares, homens, costumes, muitos têm o cunho do rei que os enobreceu. De onde vieram fidalguias e trajes, se não do 
gosto que os reis tiveram deles: Sempre se disse: 'Tal rei folgava em tal lugar, fez tal casta honrada, era monteiro, vestia as armas, estimava as letras e outros exercícios, prazer de sua vida'. Reina outro, e desfaz quanto este fez. Todos vêm interpolados: um guerreiro, outro pacífico; um cobiçoso, outro liberal; um previsto, outro inábil. Isso é geral: províncias, reinos, cidades, homens, costumes, todos têm sua vez, sua frol, seu princípio e seu fim. E bem-aventurado o príncipe em cujo tempo floresceram coisas de louvor e homens de perfeita vida medraram, cá é sinal da perfeição da sua. Não há mister mais célebre à coroa que os costumes de seus povos, porque tal será o rei quais eles forem, por ser um espírito potencial da sua república (BARROS, 1983, p. 139)..$^{13}$

O sentido da assertiva de João de Barros é inerente à natureza das circunstâncias de sua formulação. Efetivamente, a centralização de poder decorrente do processo de formação dos Estados está associado à disciplinação social dos súditos. Segundo Gerhard Oestreich, "a ideia do bem comum e da boa polícia liga-se estreitamente com a ideia de disciplina" (OESTREICH, s.d., p. 196). Em síntese, ao passo que a distinção de um reino encontra-se, também, na qualidade de seus súditos, a própria dignidade do soberano define-se pela qualidade de seus povos. Daí o papel moral-pedagógico e disciplinador do príncipe.

O papel moral-pedagógico atribuído ao príncipe é perceptível no Panegírico do Rei Dom João III, escrito por João de Barros. Neste encômio, que foi lido em Évora para o rei no ano de 1533, o autor das Décadas da Ásia assinala que "é o verdadeiro ofício do rei" inventar "novas e proveitosas leis" (BARROS, 1943, p. 5) 14 inspiradas por Deus, uma vez que "V. Alteza [...] traz todos seus pensamentos em Deus. Este é a verdadeira lei, e deste nasce a verdadeira justiça" (BARROS, 1943, p. 11). Em síntese, Barros não separa o papel do príncipe das motivações religiosas, uma vez que Dom João III é resposável tanto pela paz na república, quanto pela difusão da fé cristã: "Qual príncipe converteu à Fé de Cristo tantas províncias, tanta multidão de almas, cuja bem-aventurança não pode deixar de ser comunicada com a causa dela?" (BARROS, 1943, p. 38), pergunta-se o humanista em seu encômio. Tendo em vista que sob o 
prisma de Barros, por um lado, as repúblicas poderiam se governar tanto pelas leis quanto pelos bons costumes, e por outro, que os costumes eram mais antigos que as leis, importa considerar que ao soberano, caberia a difusão - e conservação - de ambos, visto que "[...] leis e bons costumes eram necessários para a conservação da boa república” (BARROS, 1943, p. 15).

Ao passo que a dignidade do soberano é definida, também, pelos costumes de seus súditos, é importante considerar que o surgimento dos primeiros impérios modernos foram acompanhados pela necessidade de incorporar novos espaços habitados por populações culturalmente distintas e adeptas das mais diversas crenças e costumes. Sobre o assunto, John H. Elliott chamou nossa atenção para a existência de monarquias caracteristicamente compósitas no âmbito da dinâmica da formação dos estados europeus modernos. Envolvendo, muitas vezes, uma miríade de povos e territórios, a manutenção destas monarquias dependia da observância de suas leis e costumes em um ambiente marcadamente descontínuo e heterogêneo: desse modo, a continuidade seria forjada em termos religiosos - e simultaneamente civis -, o que permitiria a configuração de uma unidade relativa para o Estado (ELLIOT'T, 1992). Por outro lado, uma vez que o governo depende, também, do consenso do governado, é imperativo que se respeite minimamente a cultura local (PAGDEN, 2002). Por isso, no caso de uma monarquia católica como a portuguesa, cujo poder fundamentava-se também na religião, o universalismo cristão permitiu a inclusão da diversidade. Sem dúvida, é preciso assinalar que é a possibilidade de conversão à fé que marca a diferença entre a figura do bárbaro para um cristão do século XVI e a figura do bárbaro da época helenística, enfim, a diferença entre a "congregatio fidelium" e o "oikuméne":

[...] enquanto o oikuméne era um mundo completamente fechado, a cristandade não era. O mito cristão de um só progenitor para toda a humanidade e a crença cristã na perfeição do plano divino para o mundo natural fizeram que a unidade do gênero homo sapiens fosse essencial para a antropologia e para a teologia, como o havia sido para a biologia grega (PAGDEN, 1988, p. 40). ${ }^{15}$ 
Ainda que nosso enfoque não incida sobre a retórica da alteridade, é relevante atentarmos à figuração do bárbaro, todavia associada à predisposião pela unidade característica do horizonte inclusivo que está na matriz da experiência estatal moderna. Uma vez que a modernidade se identifica com os procedimentos de disciplinamento social promovidos pelo Estado moderno (TARANTO, 2006), nosso interesse é assinalar que a dimensão defectiva inerente às ideias etnográficas da primeira modernidade pressupõem sujeição e subordinação política. Este movimento ecoa na formulação da ideia de soberania feita por Jean Bodin n'Os seis livros da República (1576), definida em termos de superioridade, como "o maior poder a comandar" (BODIN, 2011, p. 196).

Em síntese, o pressuposto de subordinação aponta para os defeitos que devem ser corrigidos por meio da normatização dos modos de fazer e de todos os procedimentos de disciplinamento em sentido mais amplo, o que garante o distanciamento do soberano frente aos diferentes grupos sociais, bem como o respeito à ordem social. Por sua vez, a experiência Ibérica assinala um primeiro movimento neste sentido, de modo que as descrições de um autor como João de Barros, "ideólogo" do Império Português, apresentam-se articuladas ao empreendimento espiritual que acompanha os interesses da monarquia portuguesa. A construção de pontes cognitivas no contexto da mobilização ibérica engendrou esteriótipos que nortearão divisões políticas e culturais que atingirão sua forma mais bem acabada no mundo contemporâneo.

Significativa, neste sentido, é a descrição de Moçambique feita por Barros, que a apresenta como um "pedaço de terra torneado de água salgada com que fica em ilha, tudo terra baixa e alagadiça", um lugar "doentio e bárbaro" em que ficou "sepultada a maior parte da gente" de uma armada que ali fizera escala para invernar. Indício evidente da pobreza de sua cultura material, suas "casas eram palhoças", sendo que as únicas construções "de taipa com eirados por cima", eram a Mesquita e as casas do Xeque (BARROS, 1778, p. 296). Ainda neste sentido, importa recuperar a descrição que o autor português faz da comarca de Toroa, região pertencente ao reino de Sofala habitada por uma gente que "é muito bárbara e todas suas casas são de madeira” (BARROS, 1777, p. 379). 
A ideia de que as faculdades intelectuais definiam a conduta moral e a capacidade de governo era comum no imaginário europeu do século XVI (PAGDEN, 1988). Com isso, a incapacidade política figura paralelamente à imagem do bárbaro e sua pobreza material.

De fato, as considerações de João de Barros a respeito da escolha do local para as construções e suas técnicas acenam para os limites da vida política local, tal como a região do Zanguebar, cuja aspereza da terra dificulta a habitação de gente política. O historiador anota que na região até mesmo os "animais, aves, frutas e sementes, tudo responde à barbaria da gente em serem feras e agrestes", por ser "áspera e estéril terra para habitação de gente política" (BARROS, 1777, p. 210). É diante da incapacidade de transformar seu meio, que o homem agreste se opõe ao político. Neste sentido, caso emblemático, também são os beduínos, considerados bárbaros por aqueles que "habitam cidades e povoações políticas" (BARROS, 1777, p. 210).

Por sua vez, os habitantes da Guiné também eram considerados bárbaros pelo cronista português:

Neste tempo o negócio de Guiné andava já corrente entre os nossos e os moradores daquelas partes, e uns com os outros se comunicavam nas coisas do comércio com paz e amor, sem aquelas entradas e saltos de roubos de guerra que no princípio houve. O que não pôde ser de outra maneira, principalmente acerca de gente tão agreste e bárbara, assim em lei e costumes, como no uso das coisas desta nossa Europa (BARROS, 1778, p. 141).

O caso da Guiné merece atenção especial quando nos lembramos que o título de "Senhor da Guiné" fora incorporado pelos Avis desde Dom João II. Se, como vimos argumentando, a qualidade e a boa fama da coroa depende também dos costumes de seus súditos, que interesse poderia haver por parte do reino de Portugal na incorporação desse título? A resposta está no comércio, visto que "o negócio de Guiné andava já corrente": definitivamente, ainda que a cobiça e os interesses estritamente materiais fossem condenáveis, o comércio era compreendido como fundamento de boa polícia; "o comércio e comutação, [...] é o meio pelo qual se concilia 
e trata a paz e amor entre todos os homens, por este comércio ser o fundamento de toda a humana polícia” (BARROS, 1778, p. 385). O comércio é um eficiente instrumento de comunicação e o trato da Guiné estava no escopo português a muito tempo e foi explorado de formas diversas (THOMAZ, 1994). Diante disso, mesmo considerado bárbaros:

[...] depois que tiveram alguma notícia da verdade pelos benefícios que recebiam, assim na alma como no entendimento, e coisas para seus usos, ficaram tão domésticos, que não havia mais que partirem os navios deste reino, e, chegados a seus portos, concorriam muitos povos do sertão ao comércio de nossas mercadorias, que lhe davam a troco de almas, as quais mais vinham receber salvação que cativeiro (BARROS, 1778, p. 141-142).

De fato, o número de cristãos na Guiné esteve em crescimento permanente ao longo dos primeiros séculos da presença portuguesa (CALDEIRA; NEVES, 2005). Entretanto, os benefícios que recebia a gente da Guiné não se limitavam à alma, mas compreendiam também o entendimento e as coisas de uso: o proveito das relações com os portugueses não se esgotava na esfera religiosa, uma vez que a salvação da alma haveria de ser acompanhada de uma "melhoria" significativa em todos os níveis da vida material. Sem dúvida, no século XVI, a economia não apenas tinha origem nas relações políticas mas situava-se dentro delas. ${ }^{16}$

Como apontamos, a cultura material era claro indício de vida política e boa polícia, de modo que as edificações ocupavam espaço notável na identificação das diferenças. Malaca é exemplar neste sentido, uma vez que foi considerada pelo cronista como "das mais populosas e de maior polícia em edifícios de todo o Mundo" (BARROS, 1777a, p. 14). Os artifícios de codificação que acompanham o fenômeno da mundialização definem um campo de circulação de ideias, juízos e esteriótipos elaborados a partir de um parâmetro hierárquico da diversidade de povos e culturas dos mais diversos lugares do mundo. No horizonte inclusivo da experiência estatal moderna, importa identificar o bárbaro para que seja 
transformado em homem político. Entretanto, a identificação do bárbaro define-se também pela homologia em face do imperativo da unidade do gênero humano inerente ao ecumenismo cristão. É isto o que permite ao cronista estabelecer uma relação de continuidade entre ocidente e oriente, tal como já observou Zoltán Biedermann em sugestivo artigo (BIEDERMANN, 2003).

$\mathrm{Na}$ crônica de João de Barros a homologia ganha contornos bem definidos no que se refere à China. Se a construção de pontes entre as quatro partes do mundo demanda a confecção de um inventário das diferenças, vale notar que apresenta também pontos em comum (GRUZINSKI, 2014). Em síntese, o cronista compara os chineses aos gregos e romanos sendo que os primeiros poderiam ser considerados ainda mais prudentes na construção de seu império, uma vez que de acordo com o historiador quinhentista, "tiveram maior prudência que os gregos, cartagineses e romanos; os quais, por causa de conquistar terras alheias, tanto se alongaram da pátria, que a vieram perder; porém os chineses não quiseram experimentar este total dano" (BARROS, 1777b, p. 196.). A comparação entre chineses e gregos foi oportunamente assinalada por António José Saraiva, que nos atentou para a efetiva conotação de tal recurso. Para ele, este confronto denota substantiva aproximação com o ideal de Antiguidade e tudo o que ele representou no contexto intelectual do Renascimento. Em vista disso, conclui: "como elogio e manifestação de admiração, era o máximo que de um humanista se podia esperar" (SARAIVA, 1972, p. 352).

O sentido da comparação estabelecida pelo cronista não prescinde da natureza das circunstâncias em que foi formulada, ou seja, um contexto intelectual que vive sob o signo da imitatio. De fato, como sugeriu Zoltán Biedermann, ao passo que a China podia servir de exemplo para o leitor português, é porque os fenômenos da vida social eram compreendidos como essencialmente semelhantes nas diversas regiões do globo (2003). E a comparação não pára por aí. Luís Filipe F. R. Thomaz sugere haver um diálogo entre os soberanos da China e de Portugal que mais parecia "uma conversa de surdos", em face das pretensões universalistas de ambos. Diante disso, o historiador atenta para a autorrepresentação do imperador chinês: 
Figurava-se o céu como um círculo, a terra como um quadrado; a projeção do céu na terra era a China, os quatro cantos o país dos bárbaros, que assim quedavam privados dos eflúvios celestes e prisioneiros da sua própria barbárie; se logravam escapar-lhe um pouco, era na medida em que vinham sorver à China as migalhas de civilidade que tombavam da mesa do Filho do Céu, a quem tinham, por isso, o dever de mandar embaixadas, a prestar tributo e vassalagem (THOMAZ, 1998, p. 88).

A China era de fato um lugar político segundo João de Barros, uma vez que seu rei, "em terra, povo, potência, riqueza e polícia é mais que todos estes outros" (BARROS, 1777, p. 320). Em suma, a noção de política sugere uma efetiva possibilidade de comparação. Por sua vez, esta comparação reside em um procedimento que opera um instrumental atrelado à especificidade do contexto intelectual português do século XVI. Se existe, de fato, alguma admiração por parte de João de Barros, ela está longe de aceitar a relatividade de sua civilização, mas se deve, principalmente, ao fato de que, para ele, as relações econômicas encontram-se no interior das relações políticas e obedecem a uma lógica que denota a possibilidade de compartilhar um imaginário comum e estabelecer pontes efetivas entre as diferentes civilizações em relação. Esta ponte é o reconhecimento dos limites do exercício do poder a partir daquilo que poderíamos chamar com muitas reservas de "soberania nacional": definitivamente, as relações econômicas entre portugueses e chineses só foram levadas a efeito "sob as condições estabelecidas pelas autoridades chinesas e não por aquelas impostas" pelos portugueses (BOXER, 2002, p. 64).

Por fim, ainda que partilhando de uma origem comum - ou seja, o pressuposto da unidade do gênero humano -, bem como da efetiva possibilidade de comunicação - principalmente por meio do comércio -, a configuração das diferenças orienta-se por meio de uma opressão simbólica sistematicamente veiculada pelos pressupostos hierarquizadores que norteiam a estruturação das relações nos mais diversos espaços de interação descritos pelo historiador quinhentista. Contudo, encontram homologia na esfera do poder, 
ou seja, nos limites à ingerência. Todavia, o reconhecimento dos limites do exercício do poder não se desdobra na admiração por outras civilizações como sugeriu Saraiva, mas sim em um ímpeto normatizador. Exemplo significativo, neste sentido, é a proposta pedagógica veiculada literalmente por João de Barros tanto em suas gramáticas, quanto em sua defesa da linguagem: franco tributário de Coluccio Salutati, para quem o conhecimento dos rudimentos gramaticais e do uso da língua seria a porta de entrada de todo discernimento espiritual e apreensão da palavra de Deus (GARIN, 1993), Barros compreende a necessidade estratégica de levar a efeito um procedimento de aculturação elementar (ROCHE, 2001) através da alfabetização infantil em português, "por ser o primeiro leite de sua criação" (BARROS, 1540, p. 1):

As armas e padrões portugueses postos em África e em Ásia, e em tantas mil ilhas fora da repartição das três partes da terra, materiais são, e pode-as o tempo gastar, porém não gastará doutrina, costumes, linguagem, que os portugueses nesta terra deixarem (BARROS, 2007, p. 53). ${ }^{17}$

Evidência notória do binômio língua e império, notemos que os portugueses é que haveriam de deixar suas marcas na esfera dos costumes, o que denota tanto pretensão ao direcionamento espiritual, quanto procedimento de segregação. Com efeito, a incorporação de costumes diversos implicaria degeneração, conhecida como barbarismo no caso específico da linguagem, compreendido como um "vício que se comete na escritura [...] ou na pronunciação", o qual em nenhuma outra parte da terra se cometia tanto quanto no reino de Portugal, "por causa das muitas nações que trouxemos ao jugo de nosso serviço” (BARROS, 1540, p. 34). Efetivamente, a mundialização ibérica define um campo de circulação de ideias a partir de um viés hierarquizador que reserva espaço de relevância tanto à cultura material quanto à linguagem, sendo esta última considerada o artifício da vida política por excelência. Ainda que a comparação com os antigos possa revelar alguma admiração e reconhecimento por uma civilização não europeia, vale lembrar que ela é sincrônica à veiculação de esteriótipos por meio da língua no 
interior da sociedade portuguesa. É imperativo sublinhar que seriam principalmente as variações locais no uso da fala que instrumentalizaria a violência simbólica inerente às diferenças que eram tecidas a partir de uma pretensa relação de subordinação dos locais onde não se reproduzisse fielmente a cultura lusa, notavelmente a língua portuguesa: "por que bem como os gregos e Roma haviam por bárbaras todas as outras nações estranhas a eles, por não poderem formar sua linguagem: assim nós podemos dizer que as nações de África, Guiné, Ásia, Brasil, barbarizam quando querem imitar a nossa" (BARROS, 1540, p. 34).

\section{Considerações finais}

Em síntese, podemos concluir que a necessidade de sujeição política foi a tônica dominante da mundialização levada a cabo pelos povos ibéricos ao longo da primeira modernidade. Esta necessidade fica evidente quando atentamos para o horizonte intelectual de uma sociedade que se entendia cosmologicamente ordenada e naturalmente estabilizada. Foi este o contexto intelectual que definiu a eficácia dos artifícios de codificação inerentes à relação de continuídade que se instaurou entre as diversas sociedades e culturas do mundo.

Em vista disso, o sentido de hierarquização subjacente à codificação das diferenças apresenta, também, pontos em comum. O caráter inclusivo compartilhado pelos enunciados dos letrados aqui apresentados não pode perder de vista os pressupostos de disciplinamento social interentes à formação do Estado moderno. Neste sentido, vale lembrar que, em oposição à tirania, o justo governo depende do consentimento do governado. Ainda assim, a manutenção das incipientes formações estatais dependia da observância de suas leis e costumes em um ambiente marcadamente descontínuo e heterogêneo. Daí um acervo de referências intelectuais orientado por uma perspectiva de conjunto coerente com um empreendimento espiritual que se estendia à esfera planetária, a partir de uma histórica relação estabelecida entre religião e política. 


\section{THE FIRST MODERNITY AND ITS INTELLECTUAL CONTEXT: POLITICAL SUBORDINATION AND MUNDIALIZATION}

Abstract: The purpose of this article is to study the formation of the modern world and its intellectual context. Considering that the idea of social order marked the European imaginary of the first modernity, we focus on the presence of judgments and stereotypes in literary production of the Iberian writers of the Renaissance. This literature takes us back to primitive Christianity, a consistent intellectual reference to the spiritual purposes of Iberian mundialization. Thus, we see that the ethnological thought of the first modernity is heir to the patristic thought, but is also linked to the experience of the formation of the modern state. In conclusion, we observed that the political subjection was the dominant tone of the mundialization.

Keywords: Iberian mundialization. Primitive christianity. Political subordination.

\section{Notas}

${ }^{1}$ Este texto, acrescido de modificações, se desdobra de nossa tese de doutorado, defendida no Departamento de História da USP, em 2013, e que contou com o financiamento da FAPESP. Por sua vez, as modificações do texto foram elaboradas no âmbito das atividades do Laboratório de Estudos de História das Ideias e Contextos Intelectuais (LEHICON) da UFV, e do desenvolvimento do projeto $A$ vocação imperial e o reino imaginário: a linguagem política portuguesa nos governos de D. Manuel e D. João III (1495-1557), que conta com financiamento do CNPq. ${ }^{2}$ A tradução do espanhol foi feita por mim. Os grifos são meus.

${ }^{3}$ A "primeira década", cujo título é Ásia de João de Barros, dos feitos que os portugueses fizeram no descobrimento e conquista dos mares e terras do Oriente foi editada em 1552, enquanto a Segunda década da Ásia de João de Barros e a Terceira década da Ásia de João de Barros foram publicadas, respectivamente, em 1553 e 1563. A Quarta década da Ásia de João de Barros foi publicada em 1615, por João Batista Lavanha, a partir dos manuscritos de João de Barros.

${ }^{4}$ Os grifos são meus. Optamos pela atualização da grafia nas transcrições uma vez que o valor semântico das palavras não fica comprometido para nosso propósito. A grafia foi atualizada por mim.

${ }^{5}$ Os grifos são meus.

${ }^{6}$ Vale aqui a referência a outros estudos que nos remetem a esta problemática; DUCHET, M. Anthropologie et histoire au siècle des Lumières. Paris: Albin Michel, 1995; FERGUSON, A. B. Utter Antiquity: perception of Prehistory in Renaissance England. Durham: Duke University Press, 1993.

${ }^{7}$ A tradução foi feita por mim. 
${ }^{8}$ A tradução foi feita por mim.

${ }^{9}$ A tradução foi feita por mim.

${ }^{10}$ A tradução foi feita por mim. Cf. tbm. GOODRUM, 2002.

${ }^{11}$ A tradução foi feita por mim. Cf. tbm. GOODRUM, 2002.

${ }^{12}$ Disponível em: < http://pinacotecabrera.org/en/collezione-online/opere/ heraclitus-and-democritus/>. Acesso em: 25 ago. 2016.

${ }^{13} \mathrm{O}$ grifo é meu.

${ }^{14}$ É válida a comparação da formulação de João de Barros com a de Nicolau Maquiavel, segundo a qual, "nunca coisa nenhuma deu tanta honra a um governante novo como as novas leis e regulamentos que elaborasse" (MAQUIAVEL, 1996, p. 137).

${ }^{15}$ A tradução foi feita por mim.

${ }^{16}$ Para esta inferência, cf. GODELIER, 1995.

${ }^{17} \mathrm{O}$ grifo é meu.

\section{Referências}

ABULAFIA, David. The Discovery of mankind. Atlantic encounters in the age of Columbus. New Haven, CT: Yale University Press, 2008.

ACOSTA, José de. Historia natural y moral de las Indias. Estudio preliminar de Edmundo O’Gorman. México: Fundo de Cultura Económica, 1962.

AGNOLIN, Adone. Jesuitas e selvagens: a negociação da fé no encontro catequético-ritual americano-tupi (séculos XVI-XVII). São Paulo: Humanitas Editorial, 2007.

ARISTÓTELES. A politica. Trad. Roberto Leal ferreira. São Paulo: Martins Fontes, 2006.

BARROS, João de. Da Asia de João de Barros e de Diogo de Couto. Da Asia de João de Barros dos feitos que os portugueses fizeram no descobrimento dos mares e terras do Oriente. Decada Primeira. Parte Primeira. Nova Edição oferecida a sua Magestade D. Maria I. Rainha Fidelíssima. Lisboa: Na Régia Officina Typografica, 1778.

. Da Asia de João de Barros dos feitos que os portugueses fizeram no descobrimento dos mares e terras do Oriente. Decada Primeira. Parte Segunda. Lisboa: Na Régia Officina Typografica, 1777.

. Da Asia de João de Barros dos feitos que os portugueses fireram no descobrimento 


\section{Rubens Leonardo Penegassi}

dos mares e terras do Oriente. Decada Segunda. Parte Segunda. Lisboa: Na Régia Officina Typografica, 1777a.

- Da Asia de João de Barros dos feitos que os portugueses fizeram no descobrimento dos mares e terras do Oriente. Decada Terceira. Parte Primeira. Lisboa: Na Régia Officina Typografica, 1777b.

. Grammatica da lingua Portuguesa. Olyssipone: Lodouicum Rotorigiu Typographum: M.D.X.L. (1540).

. Panegíricos (Panegírico de D. João III e da Infanta D. Maria). Texto restituído, prefaciado e notas pelo prof. M. Rodrigues Lapa. Lisboa: Livraria Sá da Costa, 1943.

. Ropicapnefma. Reprodução fac-similada da edição de 1532. Leitura modernizada, notas e estudo de I. S. Révah. 2 v. Lisboa: Instituto Nacional de Investigação Científica, 1983.

. Diálogo em louvor da nossa linguagem. In: Diálogos em defesa e louvor da Lingua Portuguesa. Edição, introdução e notas Sheila Moura Hue. Rio de Janeiro: 7 Letras, 2007.

BASIL. The Hexaemeron. In: Nicene and post-Nicene Fathers. Basil: Letters and Select Works. Second Series. Peabody, Mass: Hendrickson Publishers, 2004.

Bíblia de Jerusalém. Nova edição revista e ampliada. Gilberto da Silva Gorgulho et al. (Coord.). Tradução do texto em língua portuguesa diretamente dos originais. Tradução das introduções e notas de La Bible de Jérusalem, edição em língua francesa. São Paulo: Paulus, 2003.

BIEDERMANN, Zoltán. Nos primórdios da antropologia moderna: a Ásia de João de Barros. Anais de História de Além-Mar, v. IV, p. 29-61, 2003.

BODIN, Jean. Os seis livros da República. Livro Primeiro. Tradução, introdução e notas, José Carlos Orsi Morel; revisão técnica da tradução, José Ignacio Coelho Mendes Neto. São Paulo: Íncone, 2011.

BOXER, Charles R. O império marítimo português, 1415 - 1825. Trad. Anna Olga de Barros Barreto. São Paulo: Companhia das Letras, 2002.

BRAMANTE, Donato (Donato di Pascuccio). Heraclitus and Democritus. Fresco transferred to canvas, 1490 -1492. Disponível em: <http://pinacotecabrera.org/en/ collezione-online/opere/heraclitus-and-democritus/>. Acesso em: 25 ago. 2016 . 


\section{A primeira modernidade e seu contexto intelectual...}

CALDEIRA, Arlindo Manuel; NEVES, Carlos Agostinho das. A Igreja e a cultura. In: SERRÃO, Joel; OLIVEIRA MARQUES, A. H. (Dir.). Nova História da Expansão Portuguesa. A Colonização Atlântica. v. III, t. 2. Coord. Artur Teodoro de Matos. Lisboa: Editorial Estampa, 2005.

CHÂTELET, Noëlle. La aventura de comer. Trad. Isabel Izquierdo. Madrid: Ediciones Júcar, 1985.

CICÉRON. De la nature des dieux. Traduction nouvelle avec des notice et notes par Charles Appuhn. Paris Librarie Garnier Frères, 1935.

CLÉMENT D'ALEXANDRIE. Les Stromates. Introduction, texte critique et notes par Annewies Van Den Hoek. Traduction de Claude Mondésert, s. j. Paris: Les Éditions du Cerf, 2001.

COLOT, Blandine. Lactance, le 'Cicéron chretien': transmission des textes et contextes. In: BRIZAY, François et SARRAZIN, Véronique (sous la direction de). Érudition et culture savant. De l'Antiquité à l'époque moderne. Rennes: Presses Universitaires de Rennes, 2015.

DÉMOCRITE. L'atomisme ancient. Fragments et témoignages. Textes traduits par Maurice Solovine. Révision de la traduction, introduction et commentaires de Pierre-Marie Morel. Paris: Pocket, 1993.

DUCHET, M. Anthropologie et histoire au siècle des Lumières. Paris: Albin Michel, 1995.

ELliOTT, J. H. A Europe of Composite Monarchies. Past and Present, n. 137, The Cultural and Political Construction of Europe. p. 48-71, nov. 1992.

. O velho mundo e o novo 1492-1650. Trad. Maria Lucília Filipe. Lisboa: Querco, 1984.

FÉLIX, Minucio. Octavio. Introducción, traducción y notas de Víctor Sanz Santacruz. Madrid: Ciudad Nueva, 2000.

FERGUSON, A. B. Utter Antiquity: perception of Prehistory in Renaissance England. Durham: Duke University Press, 1993.

FERNÁNDEZ-ARMESTO, Felipe. Então você pensa que é humano? Uma breve história da humanidade. Trad. Rosaura Eichemberg. São Paulo: Companhia das Letras, 2007.

FOUCAULT, Michel. Tecnologias de si, 1982. Verve: Revista Semestral do NUSOL - Núcleo de Sociabilidade Libertária/Programa de Estudos Pós-Graduados em Ciências Sociais. Trad. Andre Degenszajn. PUC-SP, n. 6, p. 321-360, out. 2004.

GARIN, Eugenio. L'umanesimo italiano. Filosofia e vita civile nel Rinascimento. Roma: Editori Laterza, 1993. 


\section{Rubens Leonardo Penegassi}

GASBARRO, Nicola. Missões: a civilização cristã em ação. In: MONTERO, Paula (Org.). Deus na aldeia: missionários, índios e mediação cultural. São Paulo: Globo, 2006.

GODELIER, Maurice. Economia. In: Enciclopédia Einaudi. v. 28. Produção/ Distribuição - Excedente. Lisboa: Imprensa Nacional/Casa da Moeda, 1995.

GOODRUM, M. R. Biblical anthropology and the Idea of human Prehistory in Late Antiquity. In: History and Anthropology. v. 13, n. 2, p. 69-78, 2002.

GREGORY OF NYSSA. On the making of man. In: Nicene and post-Nicene Fathers. Gregory of Nyssa: Dogmatic Treatises, etc. Second Series. Peabody, Mass: Hendrickson Publishers, 2004.

GRUZINSKI, Serge. As quatro partes do mundo. História de uma mundialização. Trad. Cleonica Paes Barreto Mourão e Consuelo Fortes Santiago. Belo Horizonte: Editora UFMG; São Paulo: Edusp, 2014.

HARVEY, Paul. Dicionário Oxford de Literatura Clássica grega e latina. Trad. Mário da Gama Kury. Rio de Janeiro: Jorge Zahar Ed., 1998.

HESPANHA, António M. As estruturas políticas em Portugal na Época Moderna. In: TENGARRINHA, J. (Org.). História de Portugal. Bauru, SP: EDUSC; São Paulo, SP: UNESP; PORTUGAL, P'T: Instituto Camões, 2001.

- Imbecillitas. As bem-aventuranças da inferioridade nas sociedades de Antigo Regime. São Paulo: Annablume, 2010.

HODGEN, M. T. Early anthropology in the sixteenth and seventeenth centuries. Philadelphia: University of Pennsylvania Press, 1964.

LACTANCE. Institutions Divines. Livre II. Introduction, texte critique, traduction et notes par Pierre Monat. Paris, Éditions du Cerf, 1987.

LEACH, Edmund. Etnocentrismos. In: Enciclopédia Einaudi. v. 5. Anthropos Homem. Lisboa: Imprensa Nacional/Casa da Moeda, 1985.

MAQUIAVEL, Nicolau. O Príncipe. Escritos Políticos. Trad. Lívio Xavier. São Paulo: Editora Nova Cultural, 1996.

MONTANARI, Massimo. A fome e a abundância: história da alimentação na Europa. Trad. Andréa Doré. Bauru, SP: EDUSC, 2003.

MORESCHINI, Claudio e NORELLI, Enrico. História da literatura cristã antiga grega e latina. 3 v. Trad. Marcos Bagno. São Paulo: Edições Loyola, 2000 (v. II e III); 2014 (v. I).

NAY, Olivier. História das ideias políticas. Trad. Jaime A. Clasen. Petrópolis, RJ: Vozes, 2007.

Anos 90, Porto Alegre, v. 24, n. 45, p. 45-72, jul. 2017 
OESTREICH, G. Problemas estruturais do absolutismo europeu. In: HESPANHA, António Manuel. Poder e instituições na Europa do Antigo Regime. (colectânia de textos). Lisboa: Fundação Calouste Gulbenkian, s.d.

OVÍDIO. Metamorfoses. Trad. Bocage. São Paulo: Hedra, 2007.

PAGDEN, Anthony. La caida del hombre natural. El indio americano y los orígenes de la etnología comparativa. Trad. Belén Urrutia Domínguez. Madrid: Alianza Editorial, 1988.

. Povos e impérios: uma história de migrações e conquistas, da Grécia até a atualidade. Trad. Marta Miranda O’Shea. Rio de Janeiro: Objetiva, 2002.

RÉVAH, I. S. 'Antiquité et christianisme', 'anciens et modernes' dans l'oevre de João de Barros. Revue philosophique de la France et de l'étranger, n. 92, Paris, p. 165-185, 1967.

ROCHE, Daniel. As práticas de escrita nas cidades francesas do século XVIII. In: CHARTIER, Roger (Org.). Práticas de leitura. Trad. Cristiane Nascimento. São Paulo: Estação Liberdade, 2001.

RUBIÉS, Joan-Pau. Travel and ethnology in the Renaissance. South India through European Eyes, 1250-1625. Cambridge: Cambridge University Press, 2002.

SARAIVA, António José. Para a História da Cultura em Portugal. v. II. Lisboa: Publicações Europa-América, 1972.

TARANTO, Domenico. Tomás Morus (1478-1535), Tomás Campanela (15681639): o eudemonismo utópico. In: CAILLÉ, Alain et al. (Org.) História argumentada da filosofia moral e política. A felicidade e o útil. Trad. Alessandro Zir. São Leopoldo, RS: Editora Unisinos, 2006.

The Catholic Encyclopedia. s.d. Disponível em: <http://www.newadvent.org/ cathen/>. Acesso em: 3 set. 2016.

THOMAZ, Luis Filipe F. R. De Ceuta a Timor. Lisboa, Difel: 1994.

. Introdução. In: MARQUES, A. H. de Oliveira (Dir.). História dos portugueses no extremo oriente. v. 1, t. I. Em torno de Macau. Lisboa: Fundação Oriente, 1998. VALERI, Renée. Alimentação. In: Enciclopédia Einaudi. v. 16. Homo-Domesticação/Cultura material. Lisboa: Imprensa Nacional/Casa da Moeda, 1989.

Recebido em: 12/10/2016 Aprovado em: 01/03/2017 